Марина М. Петровић Јилих Универзитет у Крагујевцу Филолошко-уметнички факултет Катедра за германистику
УДК $373.1:: 82: 792$

81 '243

https://doi.org/10.18485/uzdanica.2020.17.1.6 Оригинални научни рад Примљен: 28. фебруар 2020. Прихваћен: 1. јун 2020.

\title{
УЛОГА И ЗНАЧАЈ ПОЗОРИШНЕ ПЕДАГОГИЈЕ ЗА ДИДАКТИКУ КЮИЖЕВНОСТИ НА СТРАНОМ ЈЕЗИКУ
}

$A \bar{u} c \bar{u} р а \kappa \bar{u}:$ У овом раду се теоријски разматра улога и значај позоришне педагогије у оквиру дидактике књижевности на страном језику. Након објашњења значаја и потребе за књижевно-дидактичким образовањем у високошколским оквирима, представљен је један од многобројних позоришно-педагошких модела, тзв. САФАРИ модел, као и његова примена у конкретној наставној ситуацији. Такође, предложени су критеријуми за одабир текстова који се адаптирају за сценско извођење. Спроведена квалитативна емпиријска истраживања, заснована на анализи појединачног случаја, а служећи се поступцима проблемски оријентисаног интервјуа и групне дискусије, потврдила су успешност пројекта у личном и социјалном развоју студената, као и побољшање, учвршћивање и стицање књижевних компетенција. Ово су уједно и кључни резултати истраживања. Књижевне компетенције један су од важних предуслова за разумевање књижевних текстова. Студенти су са уживањем и великим ангажовањем учествовали у пројекту позоришне педагогије, и то у четири улоге: као продуценти, реципијенти, прерађивачи и посредници књижевних текстова. Истраживања доказују да овај поступак поспешује ефикасност учења у наставној пракси, те омогућава постизање неких од основних циљева које дидактика књижевности на страном језику поставља. Стога ауторка рада предлаже увођење предмета Позоришна педагогија у универзитетску наставу дидактике и књижевности на филолошким факултетима у Србији.

Кључне речи: настава књижевности, позоришна педагогија, књижевне компетенције, лични развој, социјални развој.

\section{УВОД}

Главни циљ наставе књижевности на страном, али и на матерњем језику јесте да се код ученика пробуди жеља за читањем књижевних текстова и да се они оспособе за активно учешће у социјалном систему књижевности (Абрахам, Кепсер 20062: 55). У високошколској настави књижевности немачког говорног подручја је потребно оспособити студенте за самосталну књижевно-научну анализу и стално продубљивање књижевних компетенција, 
те за прихватање страности својствених овој врсти текстова. У ту страност спадају системска, функциона, структурна, интеркултурна, рецептивна, дискурсивна и ситуативна страност (детаљније у: Шлибар 2011: 41-50). Из страности које су својствене књижевности као уметности, а не само из језичке страности, произлазе и проблеми са којима се суочавају преводиоци. Према Валтеру Бенјамину, превод је специфична језичка форма („Übersetzung ist eine Form”) (Бенјамин 1989: IV, 9), те се тако и преводиочев задатак „мора схватити као посебан и јасно разликовати од песниковог”, а „однос између садржаја и језика у оригиналу потпуно [се] разликује од односа између садржаја и језика у преводу”. Преводилац може да репродукује оно непојмљиво, тајанствено и страно „само ако и сам пева”, јер „у преводу језик указује на неки језик виши од њега самог, па је стога увек непримерен сопственом садржају, насилан и туђ” (Исто: 15)1. Бенјамин сматра да је основни про-

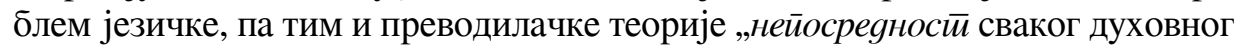
саопштавања" 2 , коју можемо да назовемо магичном, те „[у]једно овај израз, магија језика, упућује на нешто друго: на његову бескрајност" (Бенјамин 1974: 31). На читање књижевних текстова се овде може применити мото

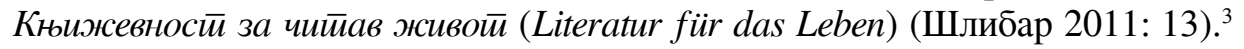
Аргументи за рад са књижевним текстовима на немачком језику у школској, али и високошколској настави су многобројни. Како наводе Абрахам и Кепcep (2006: 46), читање књижевности утиче на индивидуализацију, социјални развој, као и на развој енкултурације, што значи да утиче на стицање кључних животних компетенција. Стога је неопходно поново вратити књижевне текстове у основношколску и средњошколску наставу немачког као страног језика, а студенте који ће касније бити наставници оспособити да их у настави обрађују са задовољством и владају техникама њихове анализе. Ови циљеви могу се постићи тако што ће како школска, тако и високошколска настава књижевности на немачком језику бити оријентисана према ученицима и студентима. Књижевност у школском систему не треба да се преноси само у виду традиционалних форми - фронталне наставе или наставног разговора заснованог на питањима наставника и одговорима ученика, већ треба да јој се приђе и на друге начине, укључујући тако продуктивне методе и употребу разних медија (филм, музика, радио-драма, интернет). Након представљања предложеног позоришно-педагошког модела приступило се емпиријским квалитативним истраживањима поступцима интервјуа и групног разговора, чији су резултати укратко представљени у овом раду.

${ }^{1}$ Текст Валтера Бенјамина „Задатак преводиоца” у преводу Александре Бајазетов-Вучо, есеј „О језику уопште и језику људи” у преводу Милана Табаковића.

${ }^{2}$ Курзив у оригиналу.

${ }^{3}$ Све остале преводе у раду сачинила је ауторка рада. 


\section{ДИДАКТИКА СТРАНЕ КЊИЖЕВНОСТИ НА УНИВЕРЗИТЕТУ}

Настава књижевности у школи и настава књижевности на факултету у основи се разликују, што захтева и другачији дидактички приступ наставном процесу. Због ове разлике између школе и факултета, као и због научне оријентације наставе књижевности на факултету, дуго се сматрало да је високошколска дидактика књижевности непотреона. Као и дидактика књижевности на немачком језику, и високошколска дидактика књижевности на немачком као страном језику развијала се прилично касно и уз много баријера. Прво, не сме се испустити из вида чињеница да већина студената не само германистике, већ и других страних филологија, после завршеног факултета ради у настави. На основу свог школског и универзитетског искуства они развијају профил наставника ${ }^{4}$, који касније преузимају (Шедлих 2004: 290; Самиде 2010: 171). То значи да је врло вероватно да ће услед недостатка методских и дидактичких компетенција прибећи копирању понашања и начина рада својих наставника и наставница. Друго, суштински је важно да они когнитивно схвате и прихвате разлику између постојећих конвенција, између стварног стања и жељеног стања у наставној пракси и пре свега разумеју значај који наставник има у наставном процесу, јер осим сопствених школских искустава, начин универзитетског преношења знања, начин на који се књижевност презентује, интерпретира и дискутује представља „образац”, односно „залиху метода” за будући сопствени рад у настави (Винтерштајнер 2006: 27).

Тако, настава књижевности на немачком језику на универзитетском нивоу треба да има и улогу „стимулатора” (Холцнер, у: Винтерштајнер 2006: 27). Мишљење да универзитетску дидактику књижевности треба мењати у овом смеру заступа мали број научника у немачкој говорној средини. Разлог томе је што се веома мало научника бави дидактиком високошколске наставе књижевности како на матерњем, тако и на страном језику. У Немачкој се ово види и по томе што су на универзитетима места наставника за предмет Дидактика књижевности још увек прилично ретка, а у Србији готово да не постоје. Студенти који упишу германистику у Србији углавном немају искуства са читањем књижевних текстова на немачком језику, јер књижевни текстови у настави немачког као страног језика готово да нису заступљени. Ова тврдња заснива се на увиду и прегледу уџбеника који се користе за предмет Немачки језик у основним и средњим школама у Србији. Детаљна анализа ових уџбеника и (не)заступљеност књижевних текстова у њима превазилази

${ }^{4}$ Следећи предлог Оливере Дурбабе, а због недостатка адекватнијег термина, у даљем тексту ће се употребљавати термин насіиавник, који ће обухватати особе које се баве наставом „без обзира на степен и правни статус образовне институције у којој обављају своју активност” (Дурбаба 2011: 9). 
оквире овог истраживања. Осим тога, ауторка рада спроводи сваке године анкету међу студентима прве године германистике, у којој је једно од кључних питања да ли су пре уписа на факултет читали неки књижевни текст на немачком језику. На ово питање већина одговара негативно, па ове анкете такође потврђују горе изнету тврдњу.

\section{ПОЗОРИШНА ПЕДАГОГИЈА КАО ПРЕДМЕТ У УНИВЕРЗИТЕТСКОЈ НАСТАВИ}

Први корак у превазилажењу тешкоћа у раду са књижевним текстовима на страном језику јесте „неопходност самопосматрања, саморефлексије, вербализације ужитка и нелагоде, идентификације страности (у нама самима) [...]" (Шлибар 2011: 50)..$^{5}$ Да је адаптација књижевног текста ради његовог постављања на бину, дакле рад са књижевним текстовима по принципима позоришне педагогије, веома погодан у циљу мотивисања студената и стицања великог броја књижевних компетенција, показало је квалитативно истраживање спроведено након реализације драмског пројекта Док смо сањали (Als wir träumten) по роману немачког књижевника Клеменса Majepa (Clemens Meyer). Ова студија доказује да су учесници у представи били мотивисани на горепоменуто самопосматрање, саморефлексију, вербализацију проживљеног и идентификацију страности књижевног текста. На основу добијених резултата ауторка рада сматра да позоришна педагогија треба да буде понуђена као изборни предмет у оквиру дидактичког модула на основним филолошким студијама. Образовање у оквиру предмета Позоришна педагогија морало би, са једне стране, да образује будуће позоришне педагоге, који ће реализовати наставу, а са друге стране да буде део усавршавања будућих наставника. За конципирање овог предмета ауторка рада је преузела и прилагодила модел предмета Позоришна педагогија, који је Габриеле Черни (Gabriele Czerny) водила на Педагошком факултету у Лудвигсбургу. Ту су студенти у дуплим улогама: као они који уче и као они који подучавају. Као они који уче, студенти се упознају са методама позоришне педагогије и испробавају их, а са друге стране, као они који подучавају, они иду у основне и средње школе, где са ученицима организују наставу по методама позоришне педагогије.

${ }^{5},[\ldots]$ Notwendigkeit von Selbstbeobachtung, Selbstreflexion, Versprachlichung von Lust und Unbehagen, Identifizierung der Fremdheit (in uns selsbst) [...]” (Шлибар 2011: 50). 


\section{КРИТЕРИЈУМИ ИЗБОРА ТЕКСТОВА}

Критеријуми селекције књижевних текстова за наставу преузети су од Неве Шлибар, која скреће пажњу на то да је изазов пронаћи текст, који ученицима одговара језички и емоционално и који их стварно занима, те да са тим изазовом може да се ухвати у коштац само онај наставник који своје ученике добро познаје (Шлибар 2011: 92-98).

1. Циљеви наставе и књижевне компетенције: Када се бира текст који ће бити обрађиван у настави, у виду се морају имати циљеви наставе и оне књижевне компетенције које треба развити или учврстити. Један од важнијих циљева је активно учешће у анализи књижевног текста и дискусији после анализе, која треба да покаже какав је утицај позоришне представе на лични, социјални и естетски развој ${ }^{6}$ учесника у њој.

2. Књижевни текст као целина и дужина књижевног текста: Сваки књижевни текст је целина и као такав треба да буде обрађиван у настави.

3. Језичке компетенције, као и тематски и структурни аспекти текста треба да буду прилагођени знању и узрасту учесника у пројекту.

4. Респонзивност (Ansprechbarkeit) студената: Задовољавање овог критеријума је могуће онда када наставник добро познаје своје студенте, њихова интересовања и жеље. Књижевни текст по овом критеријуму треба да емоционално и интелектуално „погоди” студенте и изазове њихову радозналост, да буде за њих релевантан и даје им могућности за идентификацију.

5. Актуелност: Актуелност књижевног текста не значи да се морају обрађивати књижевни текстови савремене књижевности, већ да његови читаоци могу да успоставе везу између света књижевног текста и света у коме живе. Исто тако треба да се успостави веза између фикционалне слике света из текста и слике света коју студенти имају.

6. Интеркултурни аспекти: Мада лингвопрагматички аспекти не треба да заузимају централну тачку у опхођењу са књижевним текстовима, битно је да књижевни текстови садрже одређене историјске и социјалне аспекте, да показују поједине културне интерпретативне обрасце који су својствени страној култури и који могу да буду важни за добијање увида у њене специфичности, као и у специфичности другачијих норми размишљања, понашања и живљења. Зато ове аспекте треба свакако узети у обзир при избору и анализи књижевног текста.

7. Књижевно-уметничка вредност текста - канон/квалитет/вредновање: Због ограниченог времена препоручују се књижевни текстови које одликује висока књижевноуметничка вредност. Овај критеријум се не може увек по-

${ }^{6}$ Естетски развој у овом раду подразумева стицање и развој књижевних компетенција, неопходних за продуктивну и аналитичку обраду књижевних текстова. 
стићи, посебно кад се пође од тога да студенти треба да буду одушевљени текстом, да би имали мотивацију да га изнесу на бину. Проблем са вредновањем текстова савремене немачке књижевности свакако постоји, али књижевне критике у реномираним новинама и часописима, као и додељене књижевне награде за дело одређеног аутора могу да нам укажу на то да ли се ради о заиста вредном уметничком тексту.

8. Респонзивност наставника: По Неви Шлибар (2011: 97), одушевљеност текстом, енергија, радост и ентузијазам којима наставник у процесу рада са текстом зрачи, „заразна” је и преноси се на остале учеснике пројекта. На тај начин се буди ентузијазам, енергија и радост у раду са текстом.

\section{ПОЗОРИШНО-ПЕДАГОШКИ МОДЕЛ САФАРИ}

Настава књижевности на страном језику заснована на принципима позоришне педагогије је приступ књижевном тексту који подстиче развој ученика, тј. студената као индивидуа у личном и социјалном смислу, доприноси стицању и продубљивању књижевних компетенција, заснива се на конструкцији разноврсних светова, доприноси превазилажењу предрасуда, табуа, отпора према страном у тексту и у нама самима. Ако настава књижевности испуњава два основна правила модерне дидактике књижевности, она мора да:

а) представља ученицима и студентима задовољство, које проистиче из свесног доживљавања тешкоћа у раду са књижевним текстовима, подстиче их на читање, продубљује уживање у књижевном тексту, као и да

б) нелагоду у раду са вредним књижевним текстовима учини свесном, те продуктивним делањем на часу ову нелагоду и незадовољство претвори у задовољство и ужитак (Исто: 42).

Овако конципирана настава зависи у великој мери од тога колико је наставник у стању да својим ученицима на неустаљен начин приближи књижевни текст и помогне им у конструкцији његових значења. Страност књижевног текста треба да буде свесно прихваћена, а пошто као таква води сагледавању нових видика, може и треба да доведе до тога да читаоци и читатељке доживе ужитак у тексту.

Позоришна педагогија представља начин учења, а не професионални тренинг глуме. У средишту процеса налазе се ученици и студенти као глумци и као гледаоци. „Њихова позоришна игра конституише значење текста” (Черни 2010: 8). ${ }^{7}$ Због тога би о њој требало да се дискутује, а учесници у пројектима позоришне педагогије би требало да буду свесни да су својом игром

\footnotetext{
${ }^{7}$ „Ihr theatrales Spiel konstituiert die Bedeutung des Textes” (Черни 2010: 8).
} 
конституисали само једно од могућих начина читања текста. Као дидактички веома погодан показао се теоријски концепт САФАРИ (С - садржај, штоф, A - аматерски прелудијум, Ф - фигуре, А - акција, $\mathrm{P}$ - рефлексија, И - инсценирање) Габријеле Черни. Он је прилагођен потребама студената страних филологија (овде конкретно германистике) у циљу побољшања књижевних компетенција и активног учествовања у социјалном систему књижевности на занимљив и свеукупан начин. Свеукупан начин укључује и подразумева активирану мотивисаност студената да се мењају на личној и социјалној равни, као и да стичу и утврђују књижевне компетенције тумачећи, обрађујући и прерађујући књижевни текст његовим постављањем на сцену. Лични и социјални развој који учесници у позоришној представи доживљавају води стицању компетенција које омогућавају свесно сагледавање страности књижевних текстова, што је доказано анализом садржаја интервјуа и групног разговора.

\section{C-саяржај, шит̄оф}

„Основа глумљења у позоришту је конфронйација са шитофовима, йемама и йекситовима на нивоу саяржаја и на нивоу иїре, а у йойлеgу на нихо-

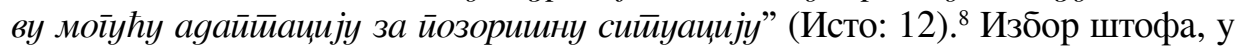
овом случају романа Док смо сањали Клеменса Мајера, одговара свим горе представљеним критеријумима селекције.

\section{A - амайерски ӥрелуяијум}

У САФАРИ моделу овај део има функцију да „глумце” припреми за позоришну игру тако што они сопственом снагом имагинације (Vorstellungsvermögen) и својим телом представљају нешто што су доживели. Тако, треба да спознају своје тело, простор у ком се крећу и групу са којом ће играти и са којом ће чинити тим. У центру ове фазе су опажај, осећај, фантазија, имагинација, тело и покрет, напетост и растерећеност. Ова веома интересантна и важна фаза, поготово код учесника који нису имали искуства у раду на бини, детаљно је описана у књизи Theater - SAFARI (Czerny 2010).

\section{$\Phi-ф$ фиіура}

Централни елемент позоришне представе је фигура као субјекат и фигура као објекат: глумац је присутан у двојаком виду, и то као лик кога глуми и као он сам. Ово искуство Габријеле Черни назива искуство разлике („Differenzerfahrung”) (Черни 2010: 15). То је искуство у коме студент спознаје лик који глуми, спознаје себе, али и другога. Ово искуство се креће

${ }^{8}$ „Die Grundlage des Theaterspielens ist die inhaltliche und spielerische Auseinandersetzung mit Stoffen, Themen und Texten im Hinblick auf ihre mögliche Adaption für die Theatersituation" (Czerny 2010: 12). Делове текста курзивом истакла је Черни. 
између опажања и доживљавања, приказивања и показивања, између конструкта свакодневне стварности и позоришне стварности.

То значи да „глумац” мора да пронађе равнотежу између личних искустава, доживљаја и емоција и оних које треба да представи ликом који глуми, мора да се уживи у лик и да се у том лику препозна. Унутрашњи свет лика који тумачи мора да добије своје отелотворење у ономе ко га тумачи. Глумац мора да доживљава све заједно са ликом који глуми, да би могао на аутентичан начин да га представи публици. Тако је глумац, тј. студент, са својим сопственим искуственим светом, својим жељама, фантазијама, конструкцијама стварности, потребама, успесима и падовима центар процеса настајања и презентовања позоришне представе. Зато је потребно да су глумац и лик нераскидива целина, а то је могуће само уколико глумац познаје унутрашњи свет лика и поима његову логику делања, поимајући на основу претходног искуства конструкт стварности која га окружује (како њега самог, тако и фигуре). Сваки глумац својој фигури даје индивидуални изражај. У овоме и јесте огроман потенцијал позоришне педагогије за наставу књижевности на страном језику.

\section{A - акција}

Акција у смислу модела Габријеле Черни превасходно подразумева импровизацију, почетак глуме, делање. Учесници у представи морају да донесу одређене одлуке, свака активност изазива активност другог на бини, потребно је ускладити покрете, одлучити ко се налази на ком делу сцене, ко када долази, одлази, како се креће итд. Прилагођена студентима страног језика и извођењу наше представе, ова фаза се у пројекту састојала из два дела.

1. Акција значи почетак рада на прочитаном тексту. Студенткиње су најпре у заједничком договору саме изабрале ликове које желе да глуме. Одлучиле су се за постављање једне дупле улоге: Данијела приповедач и Данијела актер радње. Требало је потом превазићи следећу препреку: од делова романа које су саме изабрале наставити сцене, дакле пребацити текст из медија роман у медијум драма и, друго, требало је превести на српски новонастале дијалоге. Превод на српски је био потребан јер су учесници у пројекту желели да се обрате широј публици тако што ће јој понудити титлован превод. У раду са режисером и на његов предлог одлучили су да приповедач говори на српском уз титл на немачком, а да се дијалози одвијају на немачком уз титл на српском.

2. Акција значи почетак глуме након инсценирања и драматургије. Акција значи (скоро) научен текст, кретање, динамику на бини, мимику, гестику. Акција у овом ужем смислу је у случају наше представе почела када је дошао професионални глумац крагујевачког позоришта Милош Крстовић, који потписује режију овог комада и који је са студентима радио од почетка децембра 2011. до премијерног извођења представе 15. 1. 2012. године. 


\section{$P$ - рефлексија}

Рефлексија је потребна у свакој фази настајања пројекта, иначе не би могло да дође до сврсисходне реализације пројекта. У сваком сегменту припреме текста за његово постављање на бину, у сваком сегменту рада на бини, потребно је разговарати о главним ликовима, о корацима који воде њиховом што бољем представљању публици, потребно је разговарати не само како о оригиналном, тако и о адаптираном тексту, већ и о изражајима, покретима, о емоционалном стању и социјалном функционисању глумачког тима. Рефлексија уз сваку фазу пројекта подразумева да је урађена или ће бити урађена књижевнонаучна анализа прочитаног текста, без које је немогуће поставити дело на позорницу.

\section{И-инсцениране}

Позоришна група и наставник разговарају о томе како би требало презентовати књижевни текст, на пример да ли ће се догађања одвијати хронолшки или не, како треба да изгледа сцена, који реквизити су потребни, какви ће бити костими, коју улогу ће имати музика, пројекција, филм. Инсценирањем, дакле интензивном обрадом књижевног текста, учесници у представи разумеју текст у потпуности, спознају фиктивне ликове које износе на бину, спознају себе као индивидуе и себе и своју улогу у тиму, спознају своју групу, схватају вредност тимског рада и сва ова сазнања, заједно са искуствима и доживљајима које су већ имали, они инсценирањем износе на сцену. На овај начин индивидуално разумевање текста доживљава коректуру, мења се и прераста у колективно. Они на бини морају да прикажу и конкретне чулне знакове, да би оживели приказивано.

„Употреба позоришних знакова показује да стварност на бини нити може нити хоће да се прикаже као оригинално пресликана. Естетско искуство, које ученици при томе стичу, креће се између конструкције и стварности, то значи да је позоришна игра конструисана стварност, али су ипак искуства, која се у том процесу стичу, за ученике реална, а не 'као'. Они осећају, мисле, смеју се, играју се и уче да разликују између сопствене стварности и конструисане стварности комада. Инсценирање је нова обрада штофа, стварање једне нове стварности путем фантазије и креативности ученика" (Черни 2010: 18). ${ }^{9}$

${ }^{9}$ „Der Einsatz und die Verwendung von Theaterzeichen zeigen, dass Wirklichkeit auf der Bühne nicht originalgetreu abgebildet werden kann und will. Die ästhetische Erfahrung, welche die Schüler dabei machen, bewegt sich zwischen Konstruktion und Wirklichkeit, d.h. Theaterspielen ist konstruierte Wirklichkeit, doch die Erfahrungen, die dabei gemacht werden, sind für die Schüler real und kein „als ob“. Sie fühlen, denken, lachen, spielen und lernen, zwischen der eigenen Wirklichkeit und der konstruierter Wirklichkeit des Spiels zu unterscheiden. Die Inszenierung ist die Neugestaltung des Stoffes, die Schaffung einer neuen Wirklichkeit durch die Phantasie und Kreativität der Schüler" (Черни 2010: 18). 


\section{МЕТОДОЛОГИЈА И РЕЗУЛТАТИ ИСТРАЖИВАҢА}

У овом раду представљено је квалитативно емпиријско истраживање у коме су коришћене методе, поступци, технике и транскрипција социјалних емпиријских истраживања (Мајринг 2012). Поље истраживања су студенти германистике. Они су релативно хомогена група, која има сличне обавезе на факултету и сличне изгледе за запошљавање у школама као наставници или у предузећима као преводиоци. Као будући наставници, треба да буду упознати са различитим приступима књижевним текстовима, да би касније и сами на разноврсне начине код својих ученика будили интересовање и мотивисали их за читање књижевних текстова на страном језику. Њихова индивидуална рефлексија наставе књижевности на факултету, али и у школи, као и индивидуална процена значаја и утицаја позоришне педагогије, тј. реализација представе по књижевном тексту на страном језику, али и испитивање стицања и продубљивања књижевних компетенција до сада нису били тема истраживања у германистици у Србији. Из ових разлога се може рећи да подаци добијени путем индивидуалних интервјуа и путем групног разговора имају уопштену димензију. У проблемски оријентисаном интервјуу учествовало је 10 студената, у групној дискусији њих 12, што по Мајрингу представља оптималан број испитаника у квалитативним студијама. Код ових инструмената за прикупљање података коришћена је техника Cut-and-Paste-Technik. Она омогућава исецање делова интервјуа и групне дискусије за потребе релевантних тема и њихово категорисање. Сва питања су била отвореног типа и давала су могућност промене тока интервјуа, увођења нових категорија и сагледавања личних доживљаја испитаника ${ }^{10}$.

На основу анализе садржаја интервјуа са учесницима у позоришној представи утврђено је да је књижевна социјализација код свих испитаника, осим једног, протицала на тај начин што су им родитељи, баке и деке у раном детињству читали разне врсте књижевних текстова (махом Гримове бајке) или понекад измишљали бајке и приче. Само један испитаник своју књижевну социјализацију повезује са гледањем телевизије. То значи да сви потичу из породица где се чита и да су се од раног детињства срели са књижевним текстовима.

Наставу књижевности у основној и средњој школи неки вреднују позитивно, а неки негативно. Овај аспекат углавном зависи од улоге коју је у сваком појединачном случају одиграо наставник књижевности.

Наставу књижевности немачког језика на факултету сви вреднују негативно. Само један испитаник истиче да му је веома интересантно на предавањима и један да се доласком другог наставника настава изменила у позитивном смислу. Осим односа између наставника и студената, чије испи-

\footnotetext{
${ }^{10}$ Детаљнији опис методологије истраживања у: Петровић Јилих 2016: 174-184.
} 
Петровић Јилих М. М., Улога и значај позоришне...; УЗДАНИЦА; 2020, XVII/1; стр. 115-131

тивање превазилази оквире овог рада, за студенте је битан одабир књижевних текстова, јер им је велики проблем њихова језичка и историјска страност. Рад на пројекту позоришне педагогије код свих учесника је, како је потврђено у тематском аспекту реблексија о драмском йројекйу д, довео до њиховог социјалног и личног развоја, као и развоја књижевних компетенција.

Табела 1. Категорије социјалног развоја

\section{Толеранција}

Беа: „Али људи су различити, различита су схватања свега тога, тако да они који касне једноставно немају свест о томе, не крену на време. Мене не потреса кад неко закасни на предавање, а ово је био пројекат где смо сви морали да будемо тим и кад неко не дође, то утиче на све нас, тако да сам то много лично примила на почетку, али и то се променило, јер сам схватила да ако неко не дође не треба да се ја нервирам око тога, него да се потрудим да с моје стране буде све у реду."

\section{Тимски раg}

Дубравка: „Она божићна прослава кад је била, тад смо ми већ били супер, већ смо се држали заједно, јесте видели? Ми смо певали, играли. Да, и после оне свађе у СКЦ-у."

\section{Eмӣaūuja}

Јесика: „[...] мислим да се ставиш у ципеле тих ликова, који су одбачени од друштва, да просто осетиш како се та особа осећа, онда постајеш емпата."

Ослањање на gруїе

Беа: „Тако сам могла да гледам само у Јесику и она у мене и онда ми је било лакше.”

Беа: „У другим сценама има више ликова и они једни друге некако подржавају и потпомажу."

Комуникација у іруйи

Беа: „Много се лакше опходим са њима него на почетку, зато што смо ближи, имамо заједничке тачке, имамо теме за разговор, што пре нисам имала зато што се нисам дружила ни са ким са различитих група."

Изражавање сойсӣвеної мишљења и аріуменӣовање у їруйи

Мона: „Посебно кад смо кренули да радимо, па свако хоће да исказује своје мишљење и свако мисли да је у праву и било је ту неких свађа мало, али мислим да је то било конструктивно, то нам је још више помогло да се сјединимо као група, да радимо као група и сад стварно то је изашло на прави пут."

Прихваӣање различиӣосӣи

Беа: „Кренули смо од нуле. Ми смо много различити по свему, и по знању, и по искуству, и са различитих година, по свему смо различити. И нисмо сви из Крагујевца, баш смо једна разнолика група, тако да нас је то зближило, што смо, радећи ту представу, увидели да заправо нисмо толико различити, без обзира одакле долазимо и која смо година фракултета и које смо годиште, да можемо да функционишемо као да смо сви исти."

Превазилажење ӣpegpacyga

Беа: „Нисам познавала те људе, сад смо се упознали и што више познајемо различитих људи, то си мање склон предрасудама према тим неким људима, на почетку су сви имали предрасуде једни о другима."

Јеgинсӣвеносӣ и склаgносӣ у зајеgничком раgу

Јана: „Ми смо сад буквално једно. Мада није тако деловало на почетку [...] али мислим да нас је књига, да нас је текст спојио."

Искључивање из сӣварносӣи која ӣосӣоји ван їруйе

Ања: „И онда кад смо отишли у позориште те пробе су ми биле најлепше, проводили смо тамо по цео дан, у петак смо били од ујутру до увече тамо и после кад се завршила представа имала сам, не знам ни ја, чудан осећај. Шта сад."

Oceћaj ӣpuӣagносӣu īpyūu

Беа: „Много се лакше опходим са њима него на почетку, зато што смо ближи, имамо заједничке тачке, имамо теме за разговор, што пре нисам имала зато што се нисам дружила ни са ким са различитих група." 
Табела 2. Категорије личног развоја

Ослобађање и ойушӣање

Ања: „Моја опуштеност се развијала, пошто ја никад нисам волела јавне наступе, али ја волим глуму.”

Ослобађање og cūpaха оg јавної насӣуйа ӣpeg gруїим љуудима

Миња: „То ми је био доказ да сам више самоуверена и да немам више страх од наступа као што сам имала пре."

Мона: „И сад могу да причам пред публиком на немачком језику и овако, да радим у тиму, мада сам и пре радила, нисам се ту баш много променила, али добила сам на самопоуздању, на сигурности."

Самойоуздање и вера у себе

Керстин: „У суштини ја никад нисам глумила у представи, и онда мени је... и ја сам имала велики страх, и сад имам од било каквог јавног појављивања, мени је то јако непријатно, али ја сам имала трему све док није почела представа. И онда смо стајали иза сцене и кад сам видела да су ушли и да су сели и да је све почело и само треба изаћи онда ми је некако било много лакше, некако трема се изгубила и кад је кренула представа, веровала сам људима, да ће то функционисати између учесника и веровала сам да ја то могу и веровала сам да људи око мене то могу."

Побољшање језичке комӣеӣенције

Дубравка: „Поправили смо доста језик, јер ми смо ишчитавали дело кад смо размишљали шта и како да поставимо на сцену."

Сӣицање нових живоӣних искусӣава ӣуӣем есӣеӣских искусӣава и мењање ӣоїлеgа на свеӣ Јана: „Закључила сам да се придаје значај много неким небитним стварима, ми се много нервирамо и живцирамо око глупости."

Изражавање емоција ликова ӣокреӣима

Керстин: „И имала сам проблем док није почело са музиком, док није била прва шутка, па смо се онда посвађали и после смо постали некако много слободнији и могли смо да се уживимо у то и да искажемо oceћaњa."

Изражавање сойсӣвених емоција ӣокреӣима

Мона: „Па, успела сам да управо кроз те покрете, гестикулациіу, мимику, покажем много више него што бих иначе радила, могла сам да на тај начин покажем своје унутрашње стање, неке унутрашње емоције. Рецимо кад су неке неме сцене, а треба да се покаже публици [неразумљиво] него да они знају шта ми осећамо."

Превазилажење ӣpegpacyga

Беа: „Ја мислим да сам се свугде мало помакла [...] што више различитих људи познајемо, то мање је предрасуда."

Толеранција

Дубравка: „И такође сам научила да будем мало толерантнија.”

Прихваӣање различиӣосӣи и gруїої мишљења

Керстин: „[...] и некако размишљаш о стварима о којима можда не бих размишљала, да л' свако мора да буде образован, или не знам, што на крају крајева није ни битно, заиста није битно."

Дубравка: „И да прихватим савете и слушам свачије мишљење.”

Дошло је и до развоја многих књижевних компетенција, које ће бити детаљније представљене и анализиране у једном другом раду, а овде се само набрајају:

- способност емпатије;

- способност комуникације о књижевном тексту на когнитивној, хедонистичкој и нормативној равни;

- способност да увек изнова могу да се откривају значења текста;

- способност за успостављање веза између садржаја и форме; 
- способност да се препозна индиректна употреба језика;

- способност вербализације емоционалног;

- савладавање технике детаљног и вишеструког поновљеног читања;

- способност фикционалног испробавања разних врста делања;

- способност да се издрже вишезначност и иритације које долазе из текста;

- способност аргументације сопственог конструкта значења;

- способност да се прихвате другачије конструисана значења и да се усагласе у разговору.

Због успешности спроведеног пројекта позоришне педагогије у погледу на лични, социјални и развој књижевних компетенција, у оквиру тематског

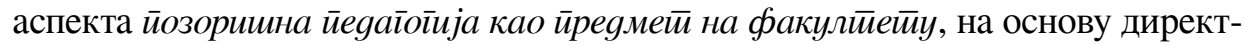
них изјава испитаника у интервјуима поставља се питање да ли испитаници сматрају да позоришну педагогију треба изучавати на факултету као посебан предмет. Сви испитаници су на ово питање одговорили са ДА. Тематизован је значај позоришне педагогије за испитанике, чије изјаве говоре у прилог увођења предмета Позоришна педагогија на факултету.

\section{- Позоришна педагогија као игра}

Иако схвата допринос и значај позоришне педагогије у томе што може да пружи „неки нов поглед на књижевност, који ће моћи да помогне у схватању књижевности", Јесика размишља о будућим пројектима позоришне педагогије који се одвајају од књижевних текстова у правцу друге уметности, наиме музике, предлажући да следећи пројекат позоришне педагогије буде „нешто типа мјузикла”.

\section{- Позоришна педагогија као терапија}

За Анђелу је позоришна педагогија предмет који треба да се користи „у медицинске сврхе, као лек за неке ствари, психосоматски лек”. Она сматра да је улога позоришне педагогије у личном и групном развоју огромна и да овај вид факултативно организоване наставе треба да има свака катедра, не само катедра за германистику. Иако она не говори о позоришној педагогији одвојеној од књижевних текстова, приписује јој функцију која није у надлежности наставе књижевности на страном језику, већ посве других струка и научних дисциплина.

- Позоришна педагогија као средство стицања језичких компетенција и алтернатива фронталној настави

Беа сматра да предмет позоришна педагогија треба да се уведе као посебан предмет, али у својој аргументацији не наводи стицање и развијање књижевних, већ језичких компетенција: „Ја мислим да то треба да буде 
обавезан предмет, не чак ни изборни и мислим да може да утиче на разне сфере, треба да се уживимо у неку другу улогу, да говоримо на немачком, да, некако је другачије кад се не седи, него се креће, кад има гестикулације и мимике, мислим да је то начин да се превазиђе та фронтална настава која је и даље засупљена и у сваком случају то треба да буде обавезан предмет, мислим да је то добра идеја, да много може да допринесе и знању језика и оријентацији у простору, да много може да утиче на ученике уопште, да се приближи том језику који учи, јер другачије је кад на конверзацији причамо нешто, него кад пишемо или препричавамо, мислим да је то много битно у настави језика."

- Позоришна педагогија као ослобађање страха од јавног наступања

Мона и Ања сматрају да у основним и средњим школама треба организовати драмске секције, да би ученици вежбали да говоре у јавности и ослободили се страха да говоре на страном језику, а све то вежбајући и језиком и покретима. Овај циљ се може постићи и на многе друге начине, који немају везе са позоришном педагогијом, а чије је спровођење финансијски, временски и организаторски много мање захтевно, као што су реферати, разна вежбања реторике, интернет презентације и слично. Предност позоришне педагогије је у већој мотивисаности и ангажовању учесника. Ипак се и овде губи из вида оријентисаност на књижевни текст, мотивацију за читање и стицање књижевних компетенција.

- Позоришна педагогија као значајано искуство за обављање будуће наставне професије

Јана би позоришну педагогију увела као обавезан предмет, јер помаже да се њени актери ослободе стега које их спутавају, помаже да се опусте, слободније изражавају пред другима и доживе неке ствари без страха од санкционисања. Ово им помаже да боље обављају своју будућу професију наставника, јер већина студената ће након завршеног факултета радити у настави, где је опхођење са ђацима од пресудног значаја за успех наставе. Тиме она исказује један од кључних аргумената за рад по методама позоришне педагогије у образовању будућих наставника: „По мени, требало би да буде обавезан, мада би вероватно био као факултативан предмет зато што много помаже да се ослободиш свега што те спутава, зато што ће половина људи овде што студира бити професори и у суштини ће имати контакте са другим људима, због изражавања, због опуштања и мислим да би људи на том предмету имали прилике да раде ствари које не би могли да раде у свом животу и да буду неко ко не би могли да буду у стварном животу, тако да мислим да би то стварно било супер." 
- Позоришна педагогија као један од начина обраде књижевног текста

Керстин: „[...] јер да би нешто представио треба да га разумеш. Одличан је начин да се приближиш тексту, јер да би извео текст на сцени ти мораш да анализираш ликове, и време у ком се то дешава, мораш да [неразумљиво] ја мислим да је то одлично.”

На основу изјава се закључује да студенти нису само спознали позитивне последице рада са методама позоришне педагогије, већ су у стању и да о њима дискутују. Проблематично је што су толико одушевљени пројектом у ком су учествовали да нису у стању да конструктивно, критички и са дистанцом реагују на позоришну педагогију.

\section{ЗАКЉУЧАК}

Овај позоришно-педагошки пројекат својеврстан је допринос дидактици књижевности на страном језику. ${ }^{11}$ „Као и свака наука, тако и дидактика књижевности хтела би нешто да побољша, и то да побољша ефикасност учења у институционализованим оквирима, полазећи од садашњег стања у настави, анализирајући га и дајући предлоге и могуће моделе на основу којих се може побољшати ефикасност учења у наставној пракси" (Петровић Јилих 2013: 198).

Учесници у пројекту позоришне педагогије се едукују на две равни: личној и социјалној и стичу и учвршћују осим кључних животних компетенција и књижевне компетенције, што је доказано представљеним квалитативним истраживањем. Студенти су актери у социјалном систему књижевности у све четири његове улоге:

- као реципијенти они књижевни текст реципирају на позадини свог целокупног комплексног искуственог и когнитивног система и приписују му значења;

- као прерађивачи они га преводе, адаптирају за сценско извођење и у свим фазама рада на његовом инсценирању комуницирају о тексту и тако га анализирају;

- као продуценти они стварају текстове о тексту и

- као посредници они покушавају да рекламирају (плакатама, брошурама, флајерима) своју позоришну представу, покушавају да је што боље продају и да је учине доступном што већем ороју гледалаца.

${ }^{11}$ Тријангулација података, представљање појединачних случајева, анализа садржаја и вредновање проблемски оријентисаних интервјуа и групне дискусије у: Петровић Јилих 2016: 184-268. 
Осим што су актери у све четири улоге, учесници у пројекту на основу комуникативних задатака које решавају у наставном процесу стварају ефикасну наставну атмосферу у конкретној просторији, развијају културу дијалога и активно и с ужитком учествују у књижевном социјалном систему. Рад на драмском пројекту је показао да је могуће да се књижевни текстови на немачком језику ефикасно обрађују на когнитивно-рефлексивној, морално-социјалној и хедонистичко-емоционалној равни и да овакав приступ раду са књижевним текстовима студентима причињава задовољство и мотивише их на читање.

\section{ЛИТЕРАТУРА}

Абрахам, Кепсер (2006): Ulf Abraham, Matthis Kepser, Literaturdidaktik Deutsch. Eine Einführung, Berlin: Erich Schmidt Verlag.

Бен јамин (1974): Walter Benjamin, Eseji, Beograd: Nolit.

Бенјамин (1980): Walter Benjamin, Gesammelte Schriften, Bd. IV/1, Tillman Rexroth (edc), Frankfurt am Main: Suhrkamp Verlag. Увид преко: www.srodstvopoizboru.wordpress.com

Бенјамин (1989): Walter Benjamin, Gesammelte Schriften, Bd. IV/1, Rolf Tiedemann et al. (edc), Frankfurt am Main: Suhrkamp Verlag.

Черни (2010): Gabriele Czerny, Theater - SAFARI. Praxismodelle für die Grundschule, Braunschweig: Bildungshaus Schulbuchverlage.

Дурбаба (2011): Olivera Durbaba, Teorija i praksa učenja i nastave stranih jezika, Beograd: Zavod za udžbenike.

Majep (2010): Clemens Meyer, Als wir träumten, Roman, Frankfurt am Main: Fischer Verlag.

Мајринг (2002): Philipp Mayring: Einführung in die qualitative Sozialforschung. Eine Einleitung zum qualitativen Denken, Weinheim, Basel: Beltz Verlag.

Петровић Јилих (2013): Marina Petrović Jilih, Didaktika književnosti kao multidisciplinarna empirijska disciplina, Nasleđe, br. 24. Kragujevac: Filološko umetnički fakultet, 187-201.

Петровић Јилих (2016): Марина Петровић Јилих, Сви смо били йексти... Caga-

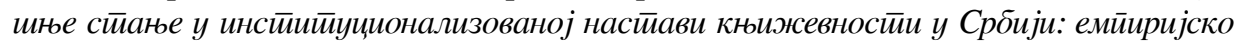

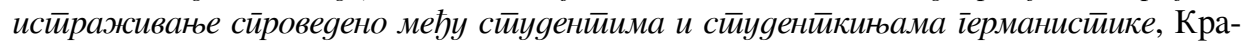
гујевац: ФИЛУМ.

Самиде (2010): Irena Samide, „Dunkles zu sagen”: Ein Bericht aus der Unterrichtspraxis, Ingeborg Bachmann weiter lesen und weiter schreiben, Ljubljana: Slovenske germanistične študije, 170-182.

Шедлих (2004): Birgit Schädlich „....an der Quelle Durst leiden”: Überlegungen zum Verhältnis von Literaturdidaktik und Hochschullehre am Beispiel der romanistischen Literaturwissenschaf, Lothar Bredella et al. (eds.), Literaturdidaktik im Dialog (Giessener Beiträge zur Fremdsprachendidaktik), Tübingen: Gunter Narr Verlag, 289-312.

Винтерштајнер (2006): Werner Wintersteiner, Die Literaturwissenschaft und ihre Didaktik, y: Susanne Hochreiter, Ursula Klingenböck (eds), Literatur-Lehren-Lernen. 
Hochschuldidaktik und germanistische Literaturwissenschaft, Wien, Köln, Weimar: Böhlau Verlag, 19-38.

Шлибар (2011): Neva Šlibar, Wie didaktisiere ich literarische Texte?: neue Maturatexte und viele andere im DaF-Unterricht, Ljubljana: Znanstvena založba Filozofske fakultete.

\section{Marina M. Petrović Jülich}

Universität in Kragujevac

Fakultät für Philologie und Kunst

Lehrstuhl für Germanistik

\section{ROLLE UND BEDEUTUNG DER THEATERPÄDAGOGIK IN DER FREMDSPRACHIGEN LITERATURDIDAKTIK}

Resümee: In diesem Beitrag wird die Rolle und Bedeutung der Theaterpädagogik im Rahmen der fremdsprachigen Literaturdidaktik näher erläutert und erklärt. Nachdem der Versuch unternommen wurde, den Bedarf an literaturdidaktischer Ausbildung im universitären Unterricht zu bekräftigen, wurde ein von vielen theterpädagogischen Modellen vorgestellt - das sogenante SAFARI-Modell und seine Anwendung in der Unterrichtspraxis. Es wurden auch Kriterien der Textauswahl vorgeschlagen, die für die szenische Darstellung adaptiert werden können. Die durchgeführten empirischen Untersuchungen und die Einzelfallanalyse, die sich der Verfahren der problemzentrierten Interviews und Gruppendisskusion bedienen, bestätigten den Erfolg des theaterpädagogischen Projektes auf dem Gebiet der persönlichen und sozialen Entwicklung der Studierenden, wie auch die Festigung und Erwerb vieler Literaturkompetenzen, die zum besseren Textverständnis führen. Das sind gleichzeitig die wichtigsten Ergebnisse der Untersuchung. Die Studierenden nahmen mit großer Begeisterung und Hingabe an diesem Projekt teil. Das geschah in allen vier Handlungsrollen: als RezipientInnen, ProduzentInnen, VerarbeiterInnen und VermittlerInnen des literarischen Textes. Untersuchungen beweisen, das dieses Unterrichtsverfahren zum effektiveren Lernen im Unterrichtspraxis führt und somit eins der Hauptziele der fremdsprachigen Literaturdidaktik erfüllt. Deswegen wird vorgeschlagen, Theterpädagogik als universitäres Unterrichtsfach an der philologischen Studienrichtungen in Serbien einzuführen.

Schlüsselwörter: Literaturunterricht, Theaterpädagogik, literarische Kompetenzen, persänliche Entwicklung, soziale Entwicklung. 